\title{
Antibody response to the $89-k D a$ outer membrane protein of Brucella in bovine brucellosis
}

\author{
J. N. LIMET, A. CLOECKAERT* $\ddagger$, G. BEZARD $\dagger$, J.VAN BROECK* and G. DUBRAY $\dagger$ \\ Facultes Universitaires Notre Dame de la Paix, 61 rue de Bruxelles, 5000 Namur, Belgium, *Unit of Experimental \\ Medicine, Catholic University of Louvain, 75 avenue Hippocrate, B-1200 Brussels, Belgium and $\dagger /$ Institut National \\ de la Recherche Agronomique, Laboratoire de Pathologie Infectieuse et d'Immunologie, 37380 Nouzilly, France
}

\begin{abstract}
Summary. The antibody response of cattle to the minor $89-\mathrm{kDa}$ outer-membrane protein (OMP) of brucella was measured by indirect ELISA with the purified protein and compared with the antibody response to smooth lipopolysaccharide (S-LPS). Pre-incubating sera with sonicated cell extracts of Escherichia coli prevented the binding of antibodies from uninfected animals to the $89-\mathrm{kDa}$ OMP, suggesting the presence of one or more cross-reactive epitopes on this protein. In cattle infected experimentally with Brucella abortus, the antibody response to the $89-\mathrm{kDa}$ OMP was later and less intense than that to S-LPS. In naturally infected cattle, $68 \%$ of animals showing an antibody response to S-LPS also showed an antibody response to the $89-\mathrm{kDa}$ OMP. Results indicate that specific epitopes of the $89-\mathrm{kDa}$ OMP in combination with those of other OMPs could be useful for diagnosis of brucellosis in cattle.
\end{abstract}

\section{Introduction}

Brucellae are gram-negative facultative intracellular bacteria that can infect many species of animals and that localise mainly in the reticulo-endothelial system and occasionally in other target organs, such as joints and placenta. In cattle, the infection can cause abortion and infertility that result in high economic loss. The major species responsible for bovine brucellosis is $B$. abortus which can be controlled to some extent by vaccination of calves with $B$. abortus $\mathrm{S}-19$, an attenuated strain. This strain is antigenically similar to virulent strains of $B$. abortus and conventional serological tests, such as the Rose Bengal plate test, milk ring test, complement fixation test and serum agglutination test, which principally measure antibody responses to smooth lipopolysaccharide (S-LPS), ${ }^{1}$ do not permit precise differentiation of vaccinated from infected cattle. Thus, there is a need to identify other antigens as alternatives to S-LPS for the elaboration of new vaccines and diagnostic tests based on antigens specific for the infected state.

S-LPS has been shown to be a protective antigen in mice by passive protection experiments with monoclonal antibodies (MAbs) ${ }^{2-5}$ and by active protection experiments with purified S-LPS or O-polysaccharide..$^{5-7}$

Possible alternatives to S-LPS include the major $B$. abortus outer-membrane proteins (OMPs) of $36-38$

Received 2 Feb. 1993; revised version accepted 11 May 1993.

$\ddagger$ Present address and address for correspondence: Institut

National de la Recherche Agronomique, Laboratoire de Pathologie et d'Immunologie, 37380 Nouzilly, France.
$\mathrm{kDa}$ and $25-27 \mathrm{kDa}^{8-11}$ They are also called group 2 porin proteins and group 3 proteins respectively. ${ }^{12,13}$ These major OMPs were found to be tightly associated with peptidoglycan (PG) ${ }^{\mathbf{1 4}, 15}$ A lipoprotein covalently linked to $\mathrm{PG}$ has also been described as a major OMP. ${ }^{16-18}$ Other OMPs identified so far are the minor OMPs of $10,16.5,19,31-34$ and $89 \mathrm{kDa}^{8}$ All these OMPs are exposed on the cell surface, as demonstrated by immuno-electronmicroscopy. ${ }^{8,18}$ The $89-\mathrm{kDa}$ OMP is probably one of the group 1 minor proteins of 88-94 kDa described by others. ${ }^{13}$ MAbs to the seven OMPs $(10,16 \cdot 5,19,25-27,31-34,36-38$ and $89 \mathrm{kDa})$ have been found to be ineffective or less efficacious than S-LPS antibodies for the prevention of B. abortus infections in mice. ${ }^{4,9}$

Antibody responses to the $10 ; 16.5 ; 19 ; 25-27$; 36-38; and $89-\mathrm{kDa}$ OMPs have been studied previously in brucella-infected cattle by immunoblot analysis and competitive ELISA with MAbs against these proteins. ${ }^{10}$ However the binding of anti-89-kDa MAbs was inhibited by sera of healthy animals as well as by sera of brucella-infected animals. This lack of specificity has now been overcome and, in the present study, the specific antibody response to the $89-\mathrm{kDa}$ OMP in experimentally and naturally infected cattle is described.

\section{Materials and methods}

\section{Bacterial strains}

The bacterial strains were obtained from the Institut National de la Recherche Agronomique, Nouzilly, Tours, France in the case of B. melitensis B115, and 
from the Institut National de Recherches Vétérinaires, Brussels, Belgium in the cases of B. abortus biovar 3, strain 7608), B. abortus biovar 9 (strain 7677-2) and E. coli $\mathrm{O} 157$.

\section{Monoclonal antibodies (MAbs)}

The anti-OMP, anti-rough-LPS (R-LPS) and antiS-LPS MAbs used were produced as described previously. ${ }^{8}$

\section{Sera from brucella-infected cattle}

Serum samples were taken from a bull experimentally infected with $2 \times 10^{10} \mathrm{cfu}$ of $B$. abortus biovar 3 (strain 7608), from cows experimentally infected with $2 \times 10^{10} \mathrm{cfu}$ of $B$. abortus biovar 3 (strain 7608) or $10^{7}$ cfu of B. abortus biovar 9 (strain 7677-2), and from naturally infected herds; the samples were provided by the Centre de Dépistage des Maladies du Bétail of Erpent. Animals from naturally infected herds were from farms where brucellosis was confirmed by the isolation of a Brucella strain. These animals gave positive results in conventional serological tests (standard tube agglutination test, Rose Bengal plate test and complement fixation test).

\section{LPS fraction}

The S-LPS fraction of B. abortus biovar 3 (strain 7608) (S-LPS of A > M specificity) was prepared by the phenol-water method. ${ }^{19}$

\section{Purification of the 89-kDa OMP}

The $89-\mathrm{kDa}$ OMP was purified from rough $B$. melitensis strain B115 cell walls prepared as described previously. ${ }^{11} \mathrm{~B}$. melitensis B115 SDS-soluble cell-wall proteins were obtained by boiling $2 \mathrm{~g}$ of cell-wall material in $100 \mathrm{ml}$ of SDS $4 \%$ solution for $10 \mathrm{~min}$. The proteins were first precipitated by adding two volumes of acetone and recovered by centrifugation $(4000 \mathrm{~g}, 20$ min, $20^{\circ} \mathrm{C}$ ) followed by solubilisation in $3 \mathrm{ml}$ of the Laemmli sample buffer for SDS-PAGE. Proteins were separated in 3-mm thick gels and bands were revealed rapidly by copper staining. ${ }^{20}$ The $89-\mathrm{kDa}$ band was cut from the gels, electro-eluted, dialysed and lyophilised. For large scale preparation, the $89-\mathrm{kDa}$ OMP was purified by gel-filtration. A Sephacryl S200 HR column $(85 \times 2.5 \mathrm{~cm})$ was equilibrated in $0.1 \mathrm{M}$ ammonium bicarbonate, $\mathrm{pH} 8$, containing SDS $0 \cdot 1 \%$. Samples of 10-20 mg of SDS-soluble proteins in $2 \mathrm{ml}$ of Laemmli sample buffer containing $1 \mathrm{~mm}$ dithiothreitol were boiled for $5 \mathrm{~min}$ at $100^{\circ} \mathrm{C}$, applied to the column and eluted at a flow rate of $16 \mathrm{ml} / \mathrm{h}$. The eluate was monitored spectrophotometrically at $280 \mathrm{~nm}$ and 3-ml fractions were collected. Samples along the first major peak were analysed by SDS-PAGE and silver staining. ${ }^{21}$ The fractions containing the $89-\mathrm{kDa}$ OMP were pooled, lyophilised, resolubilised as above in onetenth of the collected volume, and re-chromatographed on the same column. Purity of the $89-\mathrm{kDa}$
OMP was checked by SDS-PAGE and silver staining and by indirect ELISA with an anti-89-kDa MAb and MAbs specific for the other OMPs $(10,16 \cdot 5,19,25-27$, 31-34 and 36-38 kDa), S-LPS and R-LPS.

\section{ELISA}

ELISA was performed as described previously. ${ }^{8,10}$ S-LPS of $B$. abortus biovar 3 (strain 7608) at a concentration of $1 \mu \mathrm{g} / \mathrm{ml}$ or a mixture of the purified 89-kDa OMP and bovine serum albumin, both at a concentration of $1 \mu \mathrm{g} / \mathrm{ml}$ in glycine-buffered saline (GBS), pH 9.2, were coated on microtitration plates (Greiner Labortechnic-Stuttgart) by overnight incubation at $37^{\circ} \mathrm{C}$. After incubation for $1 \mathrm{~h}$, binding of MAbs (hybridoma supernates) or antibody in the bovine sera was revealed by incubation for $1 \mathrm{~h}$ more with peroxidase-conjugated goat anti-mouse immunoglobulins (Kirkegaard and Perry Laboratories Inc., Gaithersburg, MD, USA) or with peroxidaseconjugated anti-bovine IgG1 MAb $1 \mathrm{C} 8$ respectively. ${ }^{22}$ Before ELISA, diluted bovine sera were pre-incubated with sonicated $E$. coli $\mathrm{O} 157$ cells (absorbance 1.0 in PBS) for $2 \mathrm{~h}$ at $37^{\circ} \mathrm{C}$. Some samples were omitted from the pre-incubation stage, for comparison.

\section{Results}

\section{Purity of the 89-kDa OMP}

Purity of the $89-\mathrm{kDa}$ OMP was checked by SDSPAGE and silver staining (fig. 1) and by indirect ELISA with an anti-89-kDa MAb and MAbs specific

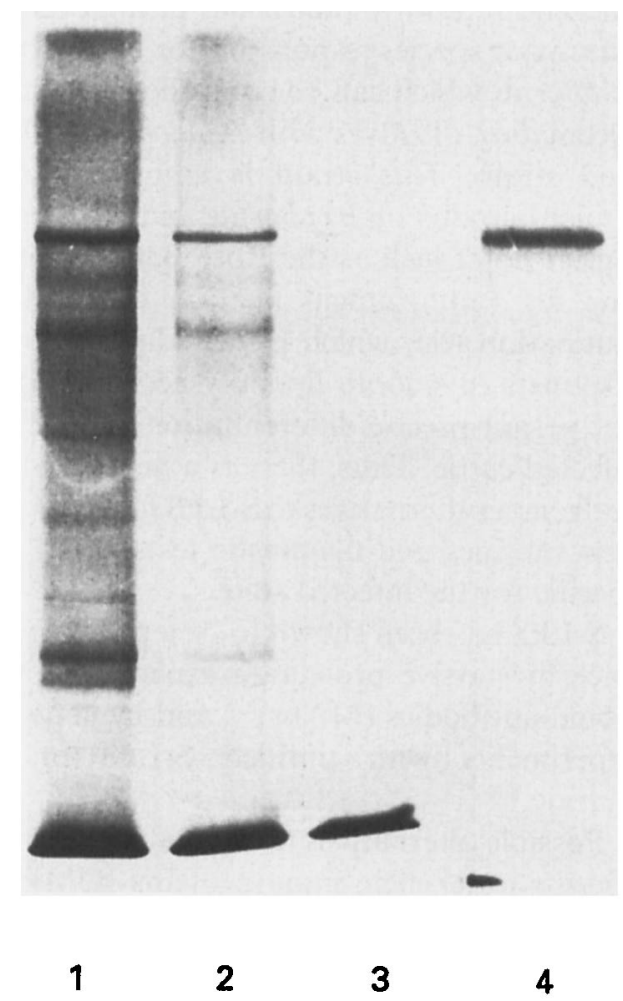

Fig. 1. Silver staining after SDS-PAGE of SDS-soluble proteins of

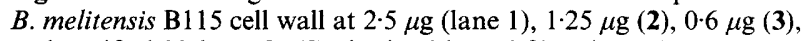
and purified 89-kDa OMP obtained by gel filtration (4). 


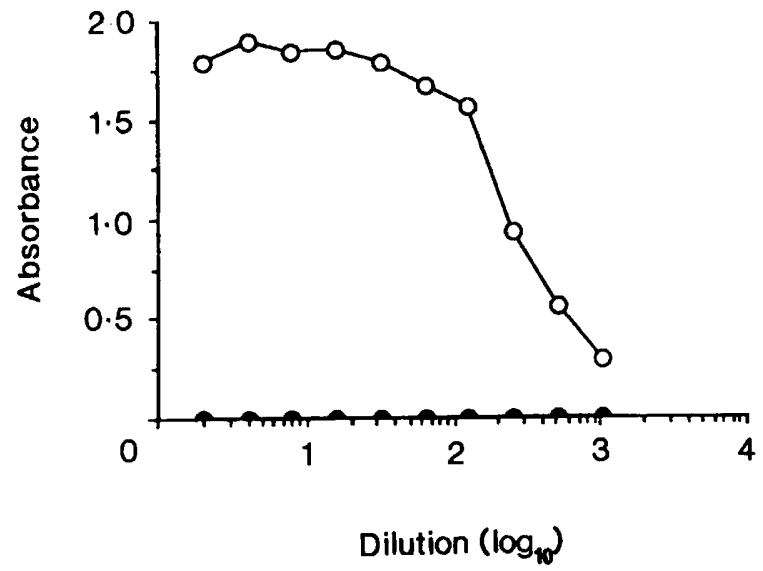

Fig. 2. Binding of anti-89-kDa MAb A53/10B02/A01 (O) and MAbs specific for other OMPs (see text), R-LPS and S-LPS (-) measured by ELISA in wells coated with purified $89-\mathrm{kDa}$ OMP.

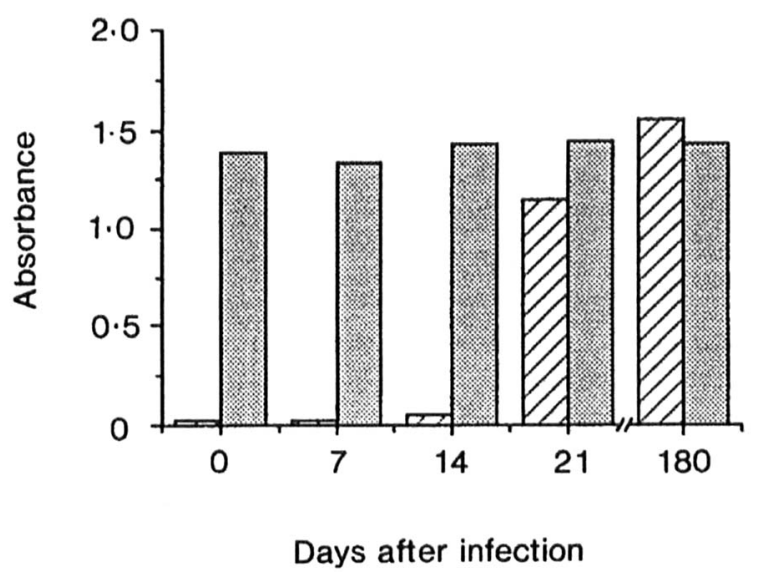

Fig. 3. Binding, measured by ELISA, to the $89-\mathrm{kDa}$ OMP-coated wells of antibodies from serum (at 1 in 100 dilution) of a bull taken before (day 0 ) and 7, 14,21 and 180 days after infection by B. abortus biovar 3 with ( $\square)$ or without (圆) pre-incubation of the serum with E. coli $\mathrm{O} 157$ sonicated cell extracts.

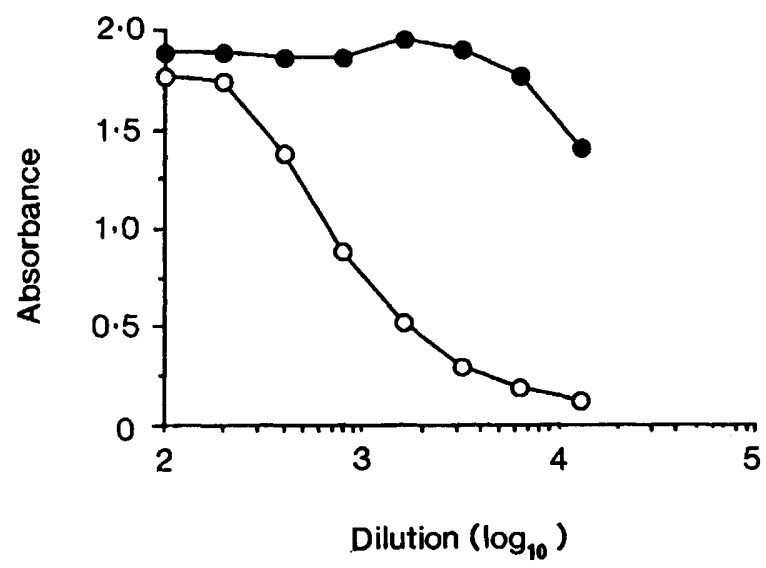

Fig. 4. ELISA with serum from a bull infected experimentally with B. abortus biovar 3 taken 6 months after infection, pre-incubated with $E$. coli $\mathrm{O} 157$ sonicated cell extracts, with S-LPS $(\bullet)$ and purified $89-\mathrm{kDa}$ OMP $(\mathrm{O})$ as coating antigens.

for the other OMPs, S-LPS and R-LPS. Only the anti89-KDa MAb bound to the purified 89-kDa OMP (fig. 2), suggesting the absence of significant contamination by the $10 ; 16.5 ; 19 ; 25-27 ; 31-34$; and $36-38-\mathrm{kDa}$ OMPs, S-LPS or R-LPS. a

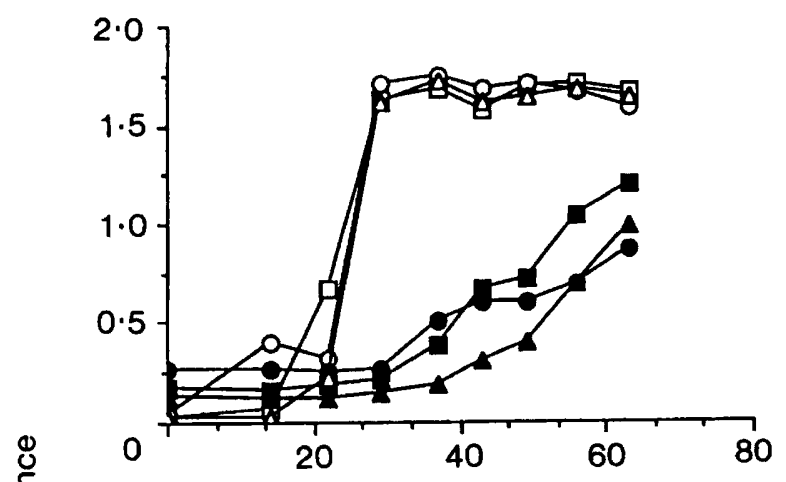

b

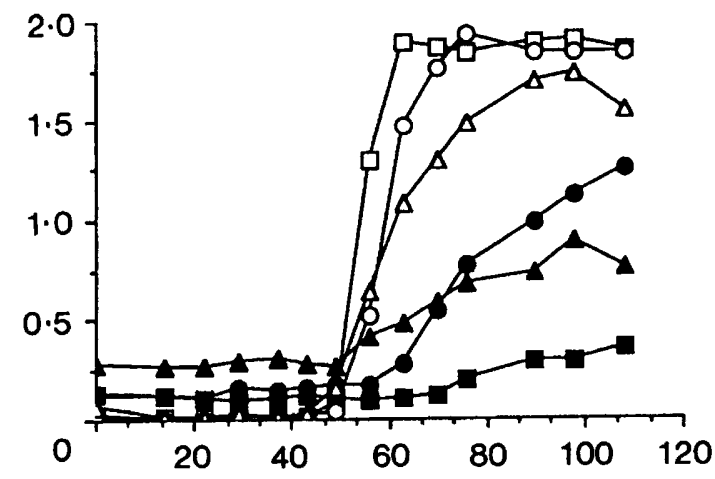

Days after infection

Fig. 5. Evolution of antibody response against S-LPS and 89-kDa OMP in heifers infected experimentally with brucella. Sera preincubated with $E$. coli $\mathrm{O} 157$ sonicated cell extracts were tested at 1 in 100 dilution. Open symbols: anti-LPS antibodies; closed symbols: anti-89-kDa antibodies. (a) Heifers infected with $2 \times 10^{10} \mathrm{cfu}$ of $B$. abortus biovar 3 in the conjunctiva; (b) heifers infected with $10^{7} \mathrm{cfu}$ of $B$. abortus biovar 9 in the conjunctiva.

\section{Antibody response in cattle infected experimentally} with B. abortus

The specific antibody response to the $89-\mathrm{kDa}$ OMP was measured by ELISA with sera from a bull taken before or 7, 14, 21 and 180 days after infection by $B$. abortus biovar 3 . In contrast to immunoblotting, with which a specific antibody response against the $89-\mathrm{kDa}$ OMP was observed, ${ }^{10}$ ELISA required pre-incubation of sera with $E$. coli $\mathrm{O} 157$ sonicated cell extracts to inhibit binding of non-specific antibodies (fig. 3). The antibody titre against the $89-\mathrm{kDa}$ OMP was lower than the titre against S-LPS (fig. 4). Other sera from animals infected experimentally with $B$. abortus were tested for antibody response to the $89-\mathrm{kDa}$ OMP and S-LPS by indirect ELISA. The antibody response to the $89-\mathrm{kDa}$ OMP was weaker than the antibody response to S-LPS and was delayed by up to several weeks depending on the infection conditions (fig. 5).

Antibody response in healthy cattle and cattle infected naturally with brucella

When pre-incubated with E. coli $\mathrm{O} 157$ sonicated cell extracts, negative control sera from 30 healthy animals 
Table. Antibody response determined by ELISA* against S-LPS and the $89-\mathrm{kDa}$ OMP in naturally infected and healthy cattle

\begin{tabular}{|c|c|c|c|c|}
\hline \multirow{2}{*}{ Animals } & \multicolumn{2}{|c|}{ S-LPS response } & \multicolumn{2}{|c|}{ 89-kDa OMP response } \\
\hline & Absorbance range & Number of animals & Absorbance range & Number of animals \\
\hline \multirow{7}{*}{ Brucella infected } & $1 \cdot 8-2 \cdot 0$ & 27 & $1 \cdot 0-1 \cdot 2$ & 5 \\
\hline & $1 \cdot 6-1 \cdot 8$ & 15 & $0.8-1.0$ & 2 \\
\hline & $1 \cdot 4-1 \cdot 6$ & 3 & $0.6-0.8$ & 7 \\
\hline & $1 \cdot 2-1 \cdot 4$ & 2 & $0.4-0.6$ & 10 \\
\hline & $1 \cdot 0-1 \cdot 2$ & 2 & $0 \cdot 2-0 \cdot 4$ & 9 \\
\hline & $<1.0$ & 1 & $0 \cdot 1-0 \cdot 2$ & 1 \\
\hline & & & $<0 \cdot 1$ & 16 \\
\hline Healthy ${ }^{\dagger}$ & $0 \cdot 046(0.021) \ddagger$ & & $0.048(0.023)$ & \\
\hline
\end{tabular}

* Sera were tested at 1 in 100 dilution.

$\dagger$ Absorbance values of infected animals below the mean absorbance +3 SD of these values were considered to be negative.

\$ Mean absorbance value of 30 negative control sera (SD).

showed no reactivity against either S-LPS or the 89 $\mathrm{kDa}$ OMP. Among the 50 anti-S-LPS-positive sera from infected animals, $34(68 \%)$ showed variable reactivity against the $89-\mathrm{kDa}$ OMP in indirect ELISA (table). However, the absorbances observed were lower than those observed for the anti-S-LPS antibodies.

\section{Discussion}

The 89-kDa OMP was purified from cell walls of $B$. melitensis $\mathrm{B} 115$ to study the antibody response in infected cattle. This rough strain is currently used for extraction of R-LPS ${ }^{8,23}$ and protein antigens ${ }^{8,10,14,24-26}$ for testing humoral and cellular immune responses of cattle and small ruminants.

The antibody response to S-LPS has been studied extensively, and it has been shown that the polysaccharide moiety of this molecule bears the main antigenic determinants involved in the standard serological tests for smooth brucellae. ${ }^{1}$ Antibody responses against purified OMPs in animals infected with brucella have been reported for the lipoprotein described by Gomez-Miguel et al. ${ }^{17}$ They found a serological cross-reaction between the lipoproteins of Brucella spp. and $E$. coli but considered that the anti-brucella lipoprotein antibody detected in infected animals could not be the result of antigenic stimulation by E. coli. A correlation between the antibody response against the lipoprotein and S-LPS was observed which demonstrated that the anti-lipoprotein antibody was related to brucella infection and not to infections with other gram-negative bacteria. In contrast with their results, to detect a specific antibody response with the purified $89-\mathrm{kDa}$ OMP in our study, sera had to be preincubated with $E$. coli cell extracts, suggesting the presence of epitopes of this OMP cross-reactive with $E$. coli antigens. However, MAbs specific for the 89kDa OMP did not show reactivity against $E$. coli antigens in immunoblotting and ELISA (data not shown) and probably recognised brucella-specific epitopes. Therefore, inhibition of these MAbs in competitive ELISA $^{10}$ by sera from healthy animals was probably due to cross-reactive epitopes similar enough to those recognised by the anti-89-kDa MAbs to prevent their binding to the $89-\mathrm{kDa}$ OMP.

As in the case of the lipoprotein, the antibody response to S-LPS was always more intense than the antibody response to the $89-\mathrm{kDa}$ OMP. MAbs specific for the $10 ; 16.5$ and $19-\mathrm{kDa}$ minor OMPs have been used to develop a competitive ELISA. ${ }^{10}$ When applied to the sera of 20 animals from an infected farm, these tests detected antibodies in six of the 17 sera containing anti-LPS antibodies. The indirect ELISA against the 89-kDa OMP detected antibodies in 13 of these sera, again $c .65 \%$ of sera containing anti-LPS antibodies.

These data indicate that specific epitope(s) of the 89$\mathrm{kDa}$ OMP in combination with those of other OMPs ${ }^{10}$ merit further evaluation for the diagnosis of brucellosis in cattle.

We are most grateful to J. M. Verger and M. Grayon for culture and control of bacterial strains. A. C. was supported by the Institut National pour l'Encouragement de la Recherche Scientifique dans l'Industrie et l'Agriculture. The research was also supported by a grant of the Commission of the European Communities (BAP-0123 B).

shared by the Brucella A and M smooth lipopolysaccharides. Infect Immun 1992; 60: 312-315.

3. Limet JN, Bosseray N, Garin-Bastuji B, Dubray G, Plommet M. Humoral immunity in mice mediated by monoclonal antibodies against the $\mathrm{A}$ and $\mathrm{M}$ antigens of Brucella. $J$ Med Microbiol 1989; 30: 37-43.

4. Montaraz JA, Winter AJ, Hunter DM, Sowa BA, Wu AM, Adams LG. Protection against Brucella abortus in mice with O-polysaccharide-specific monoclonal antibodies. Infect Immun 1986; 51: 961-963. 
5. Phillips M, Deyoe BL, Canning PC. Protection of mice against Brucella abortus infection by inoculation with monoclonal antibodies recognizing Brucella O-antigen. Am J Vet Res 1989; 50: 2158-2161.

6. Jacques I, Olivier-Bernardin V, Dubray G. Induction of antibody and protective responses in mice by Brucella $\mathrm{O}$ polysaccharide-BSA conjugate. Vaccine 1991; 9: 896-900.

7. Winter AJ, Rowe GE, Duncan JR et al. Effectiveness of the natural and synthetic complexes of porin and $\mathrm{O}$ polysaccharide as vaccines against Brucella abortus in mice. Infect Immun 1988; 56: 2808-2817.

8. Cloeckaert A, de Wergifosse P, Dubray G, Limet JN. Identification of seven surface-exposed Brucella outer membrane proteins by use of monoclonal antibodies : immunogold labelling for electron microscopy and enzyme-linked immunosorbent assay. Infect Immun 1990 58: $3980-3987$.

9. Cloeckaert A, Jacques I, Bosseray $\mathrm{N}$ et al. Protection conferred on mice by monoclonal antibodies directed against outermembrane-protein antigens of Brucella. J Med Microbiol 1991; 34: 175-180.

10. Cloeckaert A, Kerkhofs P, Limet JN. Antibody response to Brucella outer membrane proteins in bovine brucellosis: immunoblot analysis and competitive enzyme-linked immunosorbent assay using monoclonal antibodies. $J$ Clin Microbiol 1992; 30: 3168-3174.

11. Dubray G, Charriaut C. Evidence of three major polypeptide species and two major polysaccharide species in the Brucella outer membrane. Ann Rech Vét 1983; 14: 311318.

12. Douglas JT, Rosenberg EY, Nikaido H, Verstreate DR, Winter AJ. Porins of Brucella species. Infect Immun 1984; 44: 16-21.

13. Verstreate DR, Creasy MT, Caveney NT, Baldwin CL, Blab MW, Winter AJ. Outer membrane proteins of Brucella abortus: isolation and characterization. Infect Immun 1982; 35: 979-989.

14. Cloeckaert A, Zygmunt MS, de Wergifosse P, Dubray G Limet JN. Demonstration of peptidoglycan-associated Brucella outer-membrane proteins by use of monoclonal antibodies. J Gen Microbiol 1992; 138: 1543-1550.

15. Sowa BA, Kelly KA, Ficht TA, Frey M, Adams LG. SDSsoluble and peptidoglycan-bound proteins in the outer membrane-peptidoglycan complex of Brucella abortus. Vet Microbiol 1991; 27: 351-369.

16. Gómez-Miguel MJ, Moriyón I. Demonstration of a peptidoglycan-linked lipoprotein and characterization of its trypsin fragment in the outer membrane of Brucella spp. Infect Immun 1986; 53: 678-684.

17. Gómez-Miguel MJ, Moriyón I, Alonso-Urmeneta B, Riezu-Boj JI, Díaz R. Serological response to the outer membrane lipoprotein in animal brucellosis. Infect Immun 1988; 56: $716-718$.

18. Gómez-Miguel MJ, Moriyón I, López J. Brucella outer membrane lipoprotein shares antigenic determinants with Escherichia coli Braun lipoprotein and is exposed on the cell surface. Infect Immun 1987; 55: 258-262.

19. Leong D, Díaz R, Milner K, Rudbach J, Wilson JB. Some structural and biological properties of Brucella endotoxin. Infect Immun 1970; 1: 174-182.

20. Lee C, Levin A, Branton D. Copper staining: a five-minute protein stain for sodium dodecyl sulfate-polyacrylamide gels. Anal Biochem 1987; 166: 308-312.

21. Oakley BR, Kirsch DR, Morris NR. A simplified ultrasensitive silver stain for detecting proteins in polyacrylamide gels. Anal Biochem 1980; 105: 361-363.

22. Letesson JJ, Lostrie-Trussart N, Depelchin A. Production d'anticorps monoclonaux spécifiques d'isotypes d'immunoglobulines. Ann Méd Vét 1985; 129: 131-141.

23. Cloeckaert A, Zygmunt MS, Nicolle J-C, Dubray G, Limet JN O-chain expression in the rough Brucella melitensis strain B115: induction of O-polysaccharide-specific monoclonal antibodies and intracellular localization demonstrated by immunoelectron microscopy. J Gen Microbiol 1992; 138: 1211-1219.

24. Jones LM, Diaz R, Taylor AG. Characterization of allergens prepared from smooth and rough strains of Brucella melitensis. Br J Exp Pathol 1973; 54: 492-508.

25. Zygmunt MS, Gilbert FB, Dubray G. Purification, characterization, and seroreactivity of a 20-Kilodalton Brucella protein antigen. $J$ Clin Microbiol 1992; 30: 2662-2667.

26. Zygmunt MS, Martin J-C, Dubray G. Analysis of immune response: comparison of immunoblots after isoelectric focusing and sodium dodecyl sulfate-polyacrylamide gel electrophoresis using cytoplasmic protein extract from Brucella. FEMS Microbiol Lett 1990; 70: 263-268. 